\title{
Wheel Bug, Arilus cristatus (Linnaeus) (Insecta: Hemiptera: Reduviidae) ${ }^{1}$
}

F. W. Mead ${ }^{2}$

\section{Introduction}

The wheel bug, Arilus cristatus (Linnaeus), is a moderately common, widely distributed, beneficial assassin bug that preys on man's pest insects. However, its bite usually is more severe than a bee sting, and both nymphs and adults should be avoided or handled with caution.

\section{Synonymy}

Wygodzinsky (1949) listed the following synonyms:

\section{Genera:}

- Cimex Linnaeus

- Prionotus La Porte

- Prionides Uhler

Species:

- denticulatus Westwood
- novenarius (Say)

- patulus (Walker)

\section{Distribution}

The wheel bug occurs throughout Florida. It has been reported from Rhode Island westward through Iowa and Nebraska to California, and southward to Texas and Florida. Blatchley (1926) included Mexico and Guatemala in its range. Wygodzinsky (1949) recognized four species of Arilus in this New World genus, but only cristatus occurs in the United States.

\section{Description and Identification}

\section{Adult}

The wheel bug adult usually measures from 1 to 1.25 inches long. This assassin bug is a dark robust, grotesque creature having long legs and antennae, stout beak, large eyes on a slim head, and a prominent thoracic, semicircular crest suggesting a cogwheel or chicken's comb. This is the only insect species in the United States with such a crest. The number of teeth

1. This document is EENY-086 (originally published as DPI Entomology Circular No. 143), one of a series of Featured Creatures from the Entomology and Nematology Department, Florida Cooperative Extension Service, Institute of Food and Agricultural Sciences, University of Florida. Published: June 1999. Revised: January 2003. This document is also available on Featured Creatures Website at http://creatures.ifas.ufl.edu. Please visit the EDIS Website at http://edis.ifas.ufl.edu. Additional information on these organisms, including many color photographs, is available at the Entomology and Nematology Department website at http://entnemdept.ifas.ufl.edu/.

2. F. W. Mead, Florida Department of Agriculture and Consumer Services, Division of Plant Industry, Gainesville, FL.

The Institute of Food and Agricultural Sciences (IFAS) is an Equal Employment Opportunity - Affirmative Action Employer authorized to provide research, educational information and other services only to individuals and institutions that function without regard to race, creed, color, religion, age, disability, sex, sexual orientation, marital status, national origin, political opinions or affiliations. For information on obtaining other extension publications, contact your county Cooperative Extension Service office. Florida Cooperative Extension Service / Institute of Food and Agricultural Sciences / University of Florida / Larry R. Arrington, Interim Dean 
(tubercles) in the crest varies from eight to 12.

Females are longer and wider than males, with the abdominal margins being more widely exposed in the females. A very fine yellowish pubescence is present over most of the body, except the elytral membrane which produces bronze-colored reflections. The overall color is mostly dark brown. Variable amounts of tiny white patches or granules are scattered throughout the pubescence.

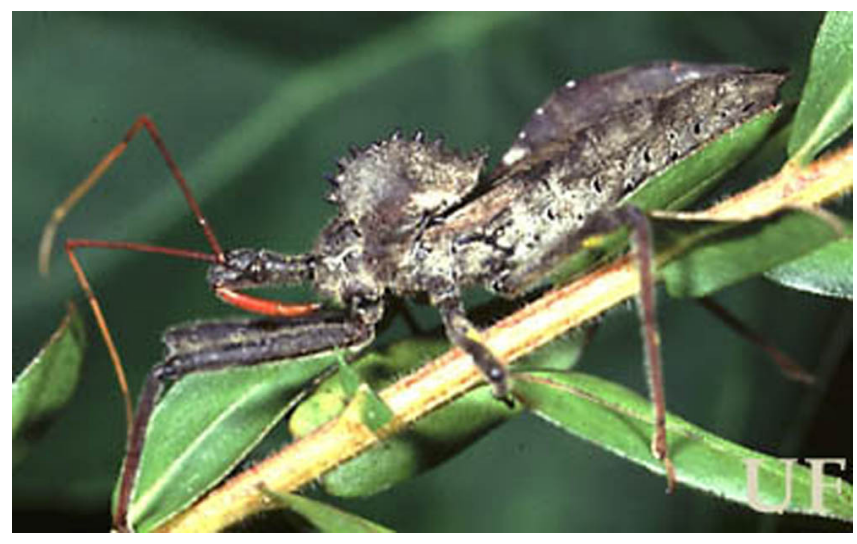

Figure 1. Adult wheel bug, Arilus cristatus (Linnaeus). Credits: James L. Castner, University of Florida

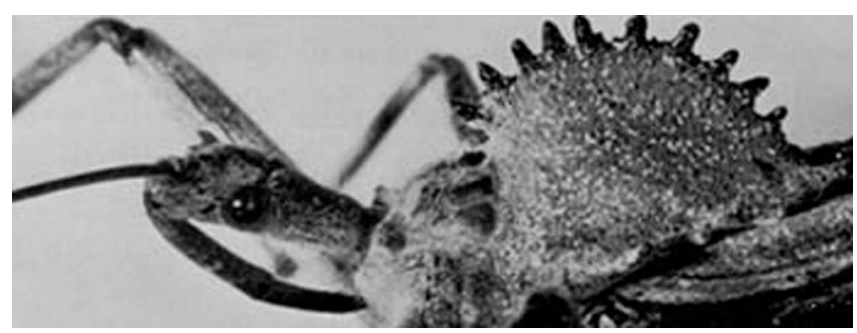

Figure 2. Close-up of head, pronotum, and "wheel" of the wheel bug, Arilus cristatus (Linnaeus). Credits: Division of Plant Industry

\section{Nymph}

Nymphs have been described in detail by Readio (1927). Smaller nymphs are bright red with black marks. The last instar nymph is darker. The "wheel" or crest is lacking on nymphs. To determine if a nymph is Arilus, consult Fracker and Usinger (1949).

\section{Eggs}

Eggs resemble miniature brown bottles with fancy white stoppers. They are $3.7 \mathrm{~mm}$ long and are laid on end, side by side, in a compact hexagonal cluster of 42 to 182 eggs (Figure 4). The cluster is glued together and covered by gummy cement that may protect the eggs from foul weather, parasites,

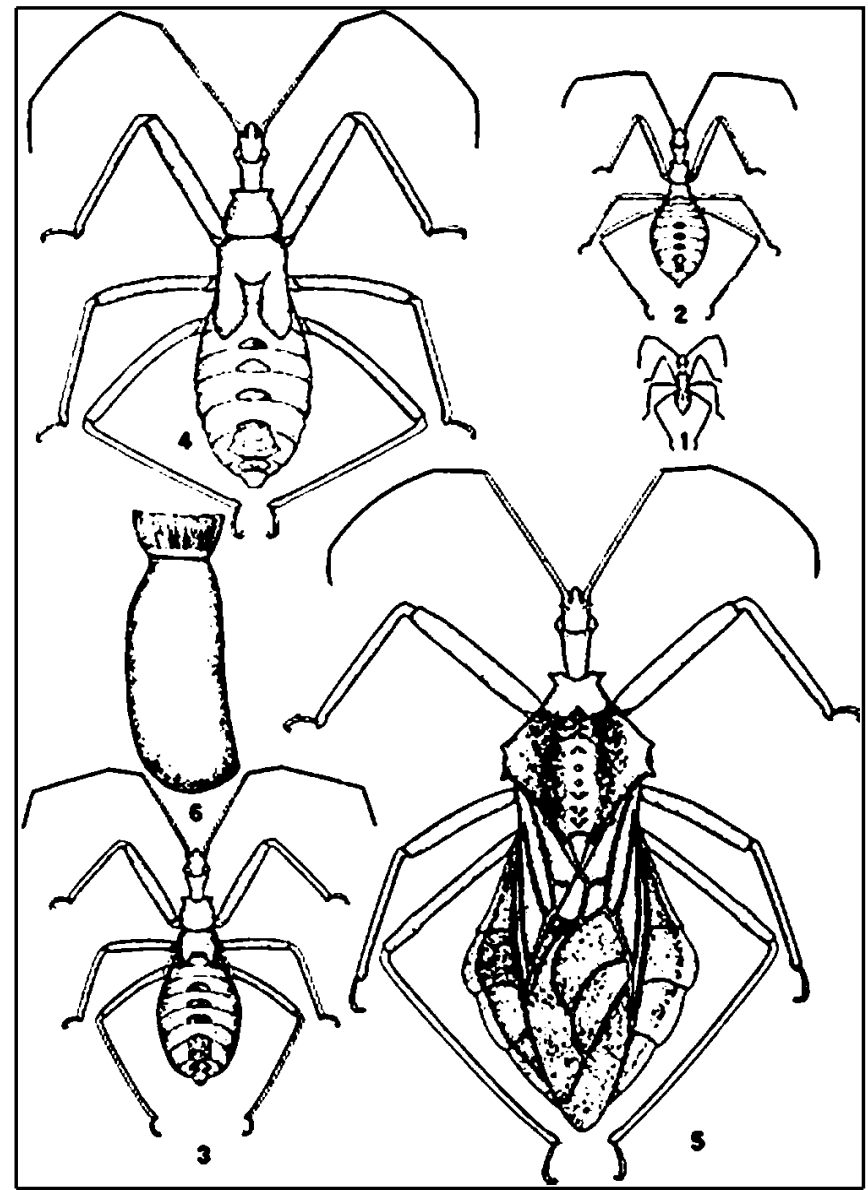

Figure 3. Life cycle of the wheel bug, Arilus cristatus (Linnaeus). 1-4: 1st, 3rd, 4th, 5th instar nymphs, repectively; 5: adult female; 6: egg 6X scale. Credits: Division of Plant Industry

and predators. Egg clusters most often are found within 4 feet of the ground attached to tree trunks and limbs, shrubs, and miscellaneous objects.

\section{Life History}

The wheel bug has one generation a year and overwinters in the egg stage. In Florida some adults live into the winter months, particularly in the central and southern portions of the state. Of approximately 60 Florida wheel bug records available to the author, nymphs were recorded from 22 April to 15 June, with most occurring in May. The limitation of nymphal records to springtime is good evidence for only one generation a year. It seems likely that nymphs are present in March, but have not been recognized and reported until they are much larger in late April. According to Todd (1937), it takes about three months developmental time from hatching of egg to adult (at Clemson, SC). This developmental time 


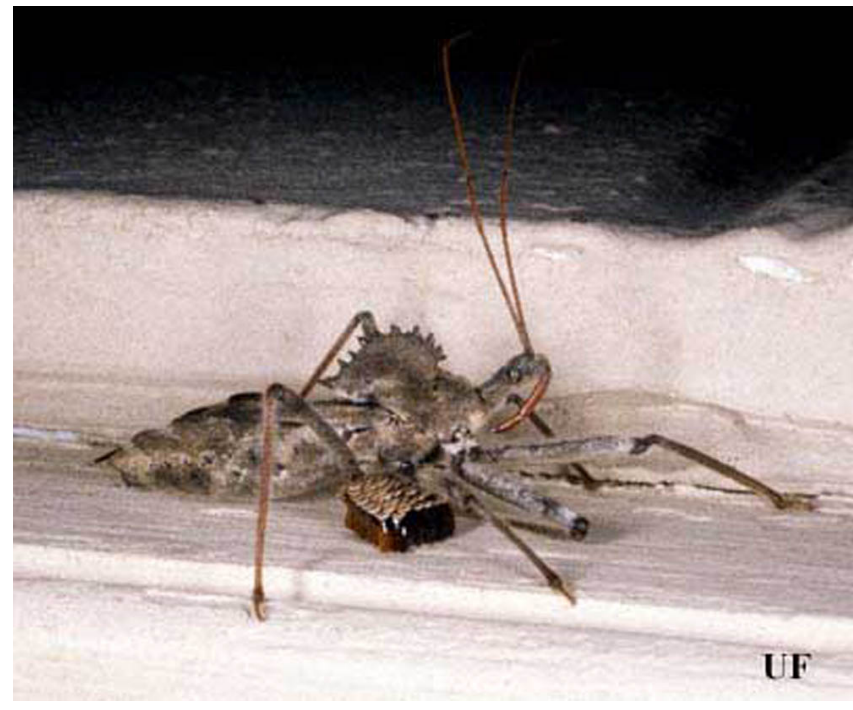

Figure 4. Female wheel bug, Arilus cristatus (Linnaeus), with eggs. The eggs were laid under an eave, and the photograph was rotated 180 degrees for display here. The female is not guarding the eggs, as she is dead. Wheel bugs overwinter as eggs. Credits: D. W. Hall, University of Florida

would account for new generation adults not being reported in Florida until late May, assuming hatching occurred approximately the first of March. Based on available records, June and July are the peak months for reports of adults in Florida. Reports drop off beginning in August, with very few in September and October, then increase again in November, with records throughout the peninsula. This suggests some aestivation during late summer and early fall. These late fall adults are mostly gravid females.

A wheel bug caught at Gainesville during December 1973 and brought into the lab, laid eggs shortly thereafter (R.I. Sailer, personal communication). The warmer climate of the South results in lingering of some adults into late fall and winter, with some late oviposition, and in earlier egg hatching next spring. Todd (1937) measured the developmental time for nymphs in outdoor cages at Clemson, SC. Average time for each of the five nymphal instars was listed as follows: I-21 days, II-14 days, III-15 days, IV-17 days, and V-32 days, totaling 99 days. Moul (1945) reported some life history information of the wheel bug at York County, PA, and provided a detailed list of prey. Stehr and Farrell (1936) reported that a caged, late-instar wheel bug nymph consumed 69 adults and 22 large larvae of the Mexican bean beetle, Epilachna varivestis
Mulsant, in 28 days. Some of the favored habitats of wheel bugs include cotton, goldenrod, sunflower, and other flowers, trunks of locust trees, citrus and pecan groves, and miscellaneous forest, shade, and fruit trees.

\section{Notes on Behavior}

Todd (1937) reported the wheel bug under natural conditions as being very vicious in the nymphal and adult stages of development. This viciousness was not so pronounced in individuals under observation in cages. He noted that specimens collected in the field become accustomed to being handled in a very short time. The wheel bug has been reported as cannibalistic, usually based on caged specimens. Nymphs have preyed upon nymphs, and Barber (1920) reported females killing and feeding upon the males soon after copulation was complete. The wheel bug is diurnal but it has been found at lights, apparently attracted to the prey coming to the lights. Froeschner (1944) counted 76 wheel bugs at one time at lights in front of a store in southern Missouri.

\section{Sounds}

The wheel bug and most other reduviids produce "chirping" sounds by rubbing the tip of the rostrum back and forth over transverse ridges on a longitudinal groove on the prosternum. Moore (1961) concluded that more evidence is necessary to establish the functions of these sounds.

\section{Scent Sacs}

Garman (1916) and Froeschner (1944) noted that wheel bugs, when captured, extrude (with little provocation) a pair of bright, orange-red scent sacs near the apex of the venter. These sacs give off a pungent scent.

\section{Attractant}

Metzger (1928) reported that wheel bugs were strongly attracted to turpentine oil.

\section{Importance as a Predator}


The wheel bug has been reported preying upon a wide variety of insects in several orders including Lepidoptera, especially Arctiidae and Noctuidae; Coleoptera, especially Chrysomelidae and Coccinellidae; Hemiptera, especially Pentatomidae; Hymenoptera, especially sawflies; and Homoptera, especially aphids upon which young nymphs feed. Unfortunately, the above groups include the beneficial lady beetles and honey bees.

Wheel bug saliva contains a toxic, paralytic substance that immobilizes and kills its victims usually within 15 to $30 \mathrm{sec}$ after injection. Immatures of the locust leafminer, Xenochalepus dorsalis (Thunberg), are killed and fed upon while still imbedded in leaf tissue. Arilus cristatus is an especially valuable predator in forest and shade trees because it preys on the well-protected hairy caterpillars that are defoliators.

\section{Medical Importance}

When disturbed, the wheel bug can inflict a painful bite. The bite has been described variously as worse than stings from bees, wasps, or hornets. Barber (1919) and Hall (1924) described in detail the effects of such bites. In general, initial pain often is followed by numbness for several days. The afflicted area often becomes reddened and hot to the touch, but later may become white and hardened at the puncture area. Occasionally, a hard core may slough off, leaving a small hole at the puncture site. Healing time varies but usually takes two weeks and may take half a year. Smith et al. (1958) reviewed the literature concerning wheel bug bites and concluded that serious or prolonged effects from these bites usually are due to secondary infection or an individual hypersensitivity.

\section{First Aid and Home Treatment}

Readio (1927) quoted Townend Glover's report that repeated applications of ammonia water were helpful in relieving pain from the bite. Smith et al. (1958) reported that application of magnesium sulfate soaks was recommended.

\section{Selected References}

Barber GW. 1919. On the bite of Arilus cristatus. Journal of Economic Entomology 12: 466.

Barber GW. 1920. Notes on the oviposition and food of the wheel-bug (Arilus cristatus Linn.) (Hemip. Heter.). Entomological News 31: 107.

Blatchley WS. 1926. Heteroptera or true bugs of Eastern North America, with especial reference to the faunas of Indiana and Florida. Nature Publishing Company, Indianapolis, IN. 1116 p.

Fracker SB., and Usinger RL. 1949. The generic identification of Nearctic reduviid nymphs (Hemiptera). Annals of the Entomological Society of America 42: 273-278.

Froeschner RC. 1944. Contributions to a synopsis of the Hemiptera of Missouri, Pt. III. American Midland Naturalist 31: 638-683.

Garman H. 1916. The locust borer (Cyllene robiniae) and other insect enemies of the black locust. Kentucky Agricultural Experiment Station Bulletin 200: 99-135.

Hall MC. 1924. Lesions due to the bite of the wheel-bug, Arilus cristatus (Hemiptera; Reduviidae). Journal of the Washington Academy of Science 14: 204.

Koehler PG, Short DE ,and Fasulo TR. (1998). Pests In and Around the Home. UF/IFAS, SW-126.

Metzger FW. 1928. Turpentine oil as an attractant of the wheel bug (Arilus cristatus L.). Journal of Economic Entomology 21: 431-432.

Mizell RF, Short DE, and Fasulo TR. (May 1998). WoodyPest. UF/IFAS. http://woodypest.ifas.ufl.edu/ (July 1999).

Moore TE. 1961. Audiospectrographic analysis of sounds of Hemiptera and Homoptera. Annals of the Entomological Society of America 54: 273-291.

Moul ET. 1945. Notes on Arilus cristatus (Linnaeus) in York County, Pennsylvania and on its prey (Heteroptera: Reduviidae). Enttomological News 56: 57-59. 
Readio PA. 1927. Biology of the Reduviidae of America north of Mexico. Kansas University Science Bulletin 17: 1-291.

Smith FD, Miller NG, Carnazzo SJ, and Eaton WB. 1958. Insect bite by Arilus cristatus, a North American reduviid. American Medical Association Arch. Derm. 77: 324-333.

Stehr WC, and Farrell W. 1936. Two hemipterous enemies of the Mexican bean beetle in Ohio. Ohio Journal of Science 36: 332-333.

Todd JN. 1937. Life history of the wheel-bug, Arilus cristatus (Linn.) (Hemiptera: Reduviidae). Entomological News 48: 226-228.

Wygodzinsky P. 1949. Elenco sistematico de los Reduviiformes Americanos. Univ. Nac. Tucuman, Inst. Med. Reg. (Pub. No. 473), Monograph No. 1: 1-102. 